\title{
Literature and the Political: Multilingualism and Exophony in Contemporary Baltic and German- Language Culture
}

\author{
MARKO PAJEVIĆ
}

Multilingualism is the norm. Many people, particularly in the Western world, might feel that it is extraordinary when people can function in two or more languages; however, the majority of people in the world have this ability. And that has always been the case. There is no place in this world where there is not a mix of cultures and languages, and that on diverse levels. Not only is every language in itself multilingual, with different language levels and language fields of considerable variation, but also every language has become what it is only through an exchange with many other languages. People of different cultures and languages have always and everywhere lived together or traded with each other - trade in goods as well as in ideas. Such an exchange of ideas is indeed the basis of all cultural development.

The role of translation is immense in any culture and it has been said for good reason that the language of Europe (and beyond, evidently) is translation. ${ }^{1}$ Or that Europe is born out of and in translation (Meschonnic 1999: 32). Our civilisation is inconceivable without translations; it builds on the Bible and Greek philosophy, both hardly ever read in the original. And Christianity is obviously imported from Asia. The idea of monolingualism is a construct which is completely apart from the reality of our linguistic condition (cf. Yildiz 2012).

Languages are worldviews, Weltansichten, according to Wilhelm von Humboldt (Humboldt IV: 27). The language we speak provides us with a perspective on the world. Our conception of the world is related to our concepts, and concepts are words, parts of language. Language thus determines our relationship with the world, including with ourselves. That does not mean that we should think of a national language as a prison of the mind - we can individually think beyond the conventions of our language, and we do so all the time (Trabant 2003: 277). So much so, that we could even say that every individual has their own individual language, formed by individual experiences and

1 Famously so by Umberto Eco in a paper at the Congress for Literary Translation, 14 November 1993 in Arles, France. 
PAJEVIĆ

associations. In a way, there are as many worldviews as there are individuals. However, up to a certain degree, our thinking, which equals our language according to Humboldt, is shaped by our national language. When we speak more languages, then, they all participate in the shaping of our overall worldview. Multilingualism is the prime possibility of escaping preconceived ideas. Several worldviews overlap and in this process new ideas and ways of seeing the world emerge. Such linguistic interferences have a creative effect. They allow us to shift and widen our perspectives. With reference to Ludwig Wittgenstein's famous phrase "Die Grenzen meiner Sprache bedeuten die Grenzen meiner Welt." (The limits of my language mean the limits of my world.) (Wittgenstein 1922: Satz 5.6), we understand that multilingualism is a delimitation, the creation of a larger world.

This thematic section offers enquiries into the interrelation of language and the political from the perspective of mainly literary multilingualism. Its approach is predominantly via exophonic literature, that is, literature written in a second acquired language and reflecting this condition in one way or another. ${ }^{2}$ Exophonic literature is a privileged field for the understanding of multilingual processes, since writers have more aware dealings with language, necessarily, and thus reflect more on their linguistic condition.

The intimate knowledge of at least two cultures of such writers evidently possesses a political interest, but that is actually not the only aspect with which the following contributions are concerned. The idea is not only to describe political backgrounds and situations or to better understand political constellations or even consequently engage with politics. Politics means here also the political of the literary itself, in the sense of Jacques Rancière (Rancière 2007), that is, the question in how far the political space is shaped by language phenomena, via the creation of new perspectives, of new ways of looking at the world.

A good number of the texts presented in this issue have been first presented at a conference at the University of Tartu on 14-15 November 2019, financed by the Baltisch-Deutsches Hochschulkontor, with the title: Mehrsprachigkeit und Politik in zeitgenössischer deutschsprachiger und baltischer Kultur (Multilingualism and Politics in Contemporary German-Language and Baltic Culture). ${ }^{3}$ This collection of articles thus presents the reader with in-depth knowledge about the background and the current developments in German-language and Baltic exophonic literatures, complemented by two

2 For this notion of exophony, cf. Arndt/Naguschewski/Stockhammer 2007 and Ivanovic 2010: 172.

3 Many of the contributions have already been published in Pajević 2020. 
linguistic-didactic contributions on the current situation of multilingualism, as well as a study on multilingualism and a Tartu song festival. It also contains an essay by the Norwegian-Estonian poet Øyvind Rangøy on his own exophonic writing.

With Baltic, I refer to the three Baltic Republics, Estonia, Latvia and Lithuania. When using the expression German-language literature, this is evidently problematic since the idea is to show that the literature in question in various ways breaks up the limits of a national language. What is meant here, is simply that we talk about literature from Germany, Austria and Switzerland. ${ }^{4}$ There are, of course, other German-language countries and regions that could, however, not be taken into consideration on this occasion.

Exophony has experienced huge interest in recent years, particularly in Germany where indeed a considerable number of very successful authors currently have a non-German cultural background and learned German only later on, mainly as children when migrating to Germany with their families, although in some cases also only learning the language as adults. The quickly growing number of studies on multilingualism and exophony is a clear indication of its political relevance in our times with their social changes and challenges. Till Dembeck, who also contributes here, even co-published a manual on the topic (Dembeck/Parr 2017), alongside a series on Literarische Mehrsprachigkeit / Literary Multilingualism in the renowned publishing house Narr/Francke/Attempto.

In spite of the general interest there is not much information about the situation in the Baltics in Germany, and knowledge about the vibrant exophonic literature scene in Germany is probably also not very developed in the Baltics. The idea behind the conference, and now the resulting publications, was therefore to initiate an exchange between the countries involved, even more so since there are such old and strong links between them. It is difficult to understand the Baltic countries, particularly Latvia and Estonia, without the German cultural input, and German culture has received many important influences from thinkers and writers from the Baltic areas when they were still partly inhabited by Baltic Germans. It is indeed difficult to make a clear distinction between the two for large portions of history. The project aimed thus at a mutual enrichment.

Research in the Baltics on multilingualism focuses so far on more historical times or rather linguistic and didactic aspects, relatively little has been done

4 The latter is actually only represented in an article by Michael Navratil in the preceding Interlitteraria number, which, together with the articles by Dinah Schöneich and Tomás Espino Barrera in the same number, was part of the conference. 
PAJEVIĆ

with respect to contemporary exophonic literature and its political implications. This is understandable particularly with respect to German, since this language, in spite of its tremendous importance before, hardly plays a role after 1919. It became actually politically inopportune, even more so after 1945.

Today, the older generations often still speak very good German, although only few young Balts learn this language, without which they hardly have direct access to their own history since until the late $19^{\text {th }}$ century, most historical sources, in Estonia and Latvia at least, are in German. English has become undoubtedly the language for international communication here as well. And contemporary exophonic literature is close to never connected to German, but mainly to Russian.

It is exactly such shifts that demonstrate how much languages are political, how much politics exercises power over languages and how much politics is aware of the importance of language and languages. Today, language policies play a major role in the delicate balance between newly won self-determination and the economically and politically necessary internationalisation. Multilingual literature and exophonic authors play a considerable role in these identity processes. This thematic section aims to provide knowledge and to open perspectives in a field equally interesting for literature and for the political.

\section{Literature}

Arndt, S., Naguschewski, D., Stockhammer, R., eds. 2007. Exophonie. Anderssprachigkeit (in) der Literatur. Berlin: Kulturverlag Kadmos.

Dembeck, T., Parr, R., eds. 2017. Literatur und Mehrsprachigkeit. Ein Handbuch. Tübingen: Narr/Francke/Attempto.

Humboldt, W. von 1903-36. Gesammelte Schriften, vol. IV, ed. by A. Leitzmann. Berlin: Behr.

Ivanovic, C. 2010. Exophonie und Kulturanalyse. Tawadas Transformation Benjamins. - C. Ivanovic, ed., Yoko Tawada. Poetik der Transformation. Beiträge zum Gesamtwerk. Tübingen: Stauffenburg, 171-206.

Meschonnic, H. 1999. Poetique du traduire. Lagrasse: Verdier.

Pajević, M., ed. 2020. Mehrsprachigkeit und das Politische. Interferenzen in zeitgenössischer deutschsprachiger und baltischer Literatur. Tübingen: Narr/Francke/Attempto.

Rancière, J. 2007. Politique de la littérature. Paris: Galilée.

Wittgenstein, L. 1963 [1922]. Tractatus logico-philosophicus. Logisch-philosophische Abhandlung. Frankfurt am Main: Suhrkamp.

Trabant, J. 2003. Mithridates im Paradies. Kleine Geschichte des Sprachdenkens. München: Beck.

Yildiz, Y. 2012. Beyond the Mother Tongue. The Postmonolingual Condition. New York: Fordham University Press. 